Pobrane z czasopisma Annales H - Oeconomia http://oeconomia.annales.umcs.pl Data: 26/04/2023 10:17:13

DOI:10.17951/h.2017.51.2.87

\begin{tabular}{cc}
\hline & A N N A L E S \\
UNIVERSITATIS & MARIAE CURIE-SKLODOWSKA \\
LUBLIN - POLONIA & SECTIOH H
\end{tabular}

Białystok University of Technology, Department of Marketing and Entrepreneurship, Faculty of Management

EWA GLIŃSKA

e.glinska@pb.edu.pl

EWELINA TOMASZEWSKA

e.tomaszewska@pb.edu.pl

\title{
Customer Preferences Related to Shopping Online ${ }^{1}$
}

Preferencje klientów związane z zakupami online

Key words: online shopping; e-consumer

Słowa kluczowe: zakupy online; e-konsument

JEL codes: M31; D12

\section{Introduction}

The development of the e-commerce market in Poland is highly influenced by the increasingly broad access to the Internet, especially broadband. In 2016, Internet access was available to $80.4 \%$ of Polish households (i.e. $4.6 \%$ more than in the previous year). In 2016 , nearly $70 \%$ of people aged $16-74$ regularly used the Internet. The highest percentage of regular users was recorded among students $(98.6 \%)$, salaried workers $(86.5 \%)$ and the self-employed (84.2\%), as well as the inhabitants of large cities (79.2\%) [GUS, 2016a].

We are able to observe the dynamic development of the Polish e-commerce market. With the increase in the popularity of online shopping, the number of re-

\footnotetext{
1 Studies have been carried out within the framework of the work S/WZ/2/2017 and financed from the science funds of the Ministry of Science and Higher Education.
} 
search projects and scientific publications on the behavior of consumers shopping online also increases. Studies of foreign literature have indicated that there are clear differences in online purchasing decision-making depending on customer age [e.g. Passyn et al. 2011]. A review of the Polish literature on the subject has pointed to the existence of a research gaps in this area.

The aim of the article is to establish the existence of statistically significant differences between certain aspects of the behaviour of consumers when shopping online and their age. The purpose of the research is to explain and focus on finding a statistically significant relationship between above indicated variables. The empirical base for the article comprises the material obtained as a result of a diagnostic survey carried out on a sample of 597 people buying over the Internet.

\section{E-consumer - definition and research directions}

The concept of the e-consumer is defined by Feldy [2012] in her deliberations, as any individual, who under the influence of internal and external conditions, decides to purchase goods or services using the Internet, and then makes an online purchase for the purpose of consumption. Wolny and Jaciow [2011] define the e-consumer as a natural person manifesting consumer needs and satisfying them with goods and services bought on the Internet. An e-consumer is, therefore, a consumer using the Internet to facilitate the process of purchase and consumption.

Recently, more and more research is being undertaken in order to identify the differences between online shopping and purchases made using the traditional method. For example, Passyn et al. [2011] identified the differences between shopping modes (traditional versus online) with regard to the age and gender of customers. In their studies, Rajamma et al. [2007] tried to prove the thesis that customers choose a specific mode of shopping, because of their own conviction concerning the fact that it is better to buy a certain type of products using one or the other mode. Toufaily et al. [2013] compared the level of customer confidence in shopping online and the traditional way [Schultz and Block 2015].

In this context, changes in the purchasing behaviour of e-consumers constitute an area of interest for many Polish authors, including Wolny [2016], Maciejewski [2016], or Pacut [2016]. Changes concern both the object of purchase (the increase in the number of products purchased via the Internet is accompanied by the change of the subjective structure of the purchase), as well as the determinants of purchase, methods of making make the purchase, and attitudes toward shopping [Wolny 2016, p. 289]. Currently, there is a need for a better understanding of online sales, given the rapid growth of this form of shopping [Schultz and Block 2015].

According to statistics, in the years 2012-2016, a steady increase in the percentage of people ordering or buying things on the Internet was recorded (increase of 11.6\%). In 2016, more than 12 million Polish people aged 16-74 (i.e. $41.9 \%$ of the population) engaged in online shopping over the past year. Compared to the EU av- 
erage, the percentage of Polish e-consumers buying over the Internet was 16\% lower. Most frequently, e-consumers decide to buy clothing and sports equipment [GUS, 2016b]. In light of the another report, Polish e-consumers prefer to buy clothing and accessories, books, CDs and movies, as well as phones, smartphones, tablets, GSM accessories [Gemius, 2016].

The motives for online shopping have not changed over the last years. The respondents include the following as the three primary motivators for shopping online: around-the-clock availability, no need to physically go to a store and more attractive prices [Gemius, 2016]. The greatest benefits of e-shopping, according to respondents, include a large selection of products, brands and stores, lower prices than traditional stores, and shopping without leaving home [TNS, 2016]. Nevertheless, in light of various reports, the weight of these factors varies according to respondents.

\section{Research methodology}

The research project included carrying out a survey with the use of the CAWI diagnostic technique among the inhabitants of Podlaskie Voivodeship.

The empirical material used in the study constitutes a part of a wider project of international character, the aim of which was to determine the differences in the behaviour of consumers shopping online, taking into account their country of residence ${ }^{2}$. The article contains references to the results of research carried out exclusively among Polish customers. The study sample consisted of 597 people, half of whom $(52 \%)$ were inhabitants of the city of Białystok, $26 \%$ of the residents of other cities in the Voivodeship, and nearly $19 \%$ of respondents lived in rural areas. In the age structure of respondents, the dominant group were the people representing the age category $18-24$ years. They accounted for $65.5 \%$ of all respondents. The remaining group (35.5\%) are the respondents older than 25 years of age.

According to identified research gap and the formulated objective of the article, the analysis of the results of studies focused on the search for the existence of statistically significant differences between certain aspects of the behaviour of consumers when shopping online and their age. In order to achieve the intended aim of the article, an attempt was made to answer the following research questions:

- Does the variable of age diversify the acquisition of each category of products when shopping online?

- Does the variable of age diversify the motivations leading people to make purchases online?

- Does the variable of age diversify the impact of individual factors on making purchases online?

2 Composition of the research team: U. Ryciuk - research coordinator, U. Widelska, E. Rollnik-Sadowska, U. Kobylińska, M. Jarocka, E. Glińska, E. Tomaszewska. 
Due to the fact that people aged 18-24 were overrepresented in the structure of the sample, a division of the sample into age groups was adopted to form an age variable of one of two values: 1 - people aged 18-24 and 2-those over 25 years of age.

In order to find answers to the posed research questions, the Mann-Whitney U test was used, which is a non-parametric equivalent of the $\mathrm{T}$ test for independent samples. It is used for testing the differences between two independent groups. Its effectiveness is similar to the effectiveness of the T test [Bedyńska and Cypryańska 2013, p. 185].

\section{Analysis and discussion of research results}

Respondents were asked to comment on the claim "I usually make purchases over the Internet...". The respondents had the 5-point Likert scale at their disposal: 5 - "strongly agree", 1 - "strongly do not agree".

The analysis of the results of answers to this question proved that the categories of products most often purchased online by respondents include: clothing, shoes, and tickets to entertainment events, electronic equipment for personal use, books and records, as well as cosmetics.

Table 1. The arithmetic mean of the categories of products purchased online

\begin{tabular}{|l|c|}
\hline \multicolumn{1}{|c|}{ Categories of products bought online } & Arithmetic mean \\
\hline Clothes & 3.17 \\
\hline Leisure tickets & 3.00 \\
\hline Shoes & 3.00 \\
\hline Electronics for person & 2.96 \\
\hline Books/records & 2.82 \\
\hline Cosmetics & 2.69 \\
\hline Tourism (trips, hotels) & 2.36 \\
\hline Electronics for home & 2.33 \\
\hline Catering services & 2.17 \\
\hline Jewellery & 2.15 \\
\hline Home and garden & 2.15 \\
\hline Toys & 2.14 \\
\hline Games & 2.13 \\
\hline Used goods & 1.99 \\
\hline Office supplies & 1.86 \\
\hline Pharmacy & 1.78 \\
\hline Furniture & 1.73 \\
\hline Goods for animals & 1.60 \\
\hline Chemistry & 1.56 \\
\hline Cars & 1.44 \\
\hline Food and drinks & 1.40 \\
\hline
\end{tabular}

Source: Authors' own study. 
The calculation of the statistics of the Mann-Whitney U test proves that the differences between the groups including younger people (under 24 years of age) and older respondents, are statistically significant when it comes to buying products in such categories as: books/records, jewellery, toys, games and cars. Younger people more frequently than older people tend to buy: games, jewellery and cars online. On the other hand, people over the age of 25 often acquire books/records and toys. In all these cases, the asymptotic significance was lower than 0.05 .

Table 2. Results of analysis using the Mann-Whitney U test

\begin{tabular}{|l|c|c|c|c|}
\hline $\begin{array}{c}\text { Categories of products } \\
\text { bought online }\end{array}$ & $\begin{array}{c}\text { Average for the } \\
\text { group of people } \\
\text { aged 18-24 years }\end{array}$ & $\begin{array}{c}\text { Average for the } \\
\text { group of people } \\
\text { aged over 25 }\end{array}$ & $\begin{array}{c}\text { Value of the } \\
\text { Mann-Whitney } \\
\text { U test }\end{array}$ & $\begin{array}{c}\text { Asymptotic bilate- } \\
\text { ral significance } \\
\mathrm{p}<0.05\end{array}$ \\
\hline Books/ records & 286.58 & 324.99 & $\mathrm{U}=33970.0$ & $\mathrm{p}=0.009$ \\
\hline Jewellery & 309.71 & 276.6 & $\mathrm{U}=34659.0$ & $\mathrm{p}=0.02$ \\
\hline Toys & 282.74 & 333.04 & $\mathrm{U}=32416.0$ & $\mathrm{p}=0.00$ \\
\hline Cars & 306.56 & 283.17 & $\mathrm{U}=35930.0$ & $\mathrm{p}=0.04$ \\
\hline
\end{tabular}

Source: Authors' own study.

The respondents were asked to comment on the statements indicating the specific reasons for making online purchases. The respondents had the 5-point Likert scale.

The analysis of the results of answers to this question revealed that the most common motivations for making online purchases include the issues related to the availability of online stores around the clock, as well as with the possibility of realization of the whole process of purchase without leaving home. An important factor is also the possibility of making comparisons of products or prices on the web. Quite often, the respondents pointed to such arguments as: a greater range of products in online stores compared to traditional shops, as well as the ability to find niche, unique products.

Table 3. Average assessment of individual motivations to make online purchases

\begin{tabular}{|l|c|}
\hline \multicolumn{1}{|c|}{ What motivates you to make purchases online? } & Average rating \\
\hline Around-the-clock availability & 4.50 \\
\hline Place (You can organize everything at home or work) & 4.46 \\
\hline Possibilities to compare (price, product) & 4.44 \\
\hline Bigger assortment & 4.28 \\
\hline Possibilities to find special products & 4.22 \\
\hline Lower prices than in traditional stores & 4.17 \\
\hline Possibilities of payment & 4.15 \\
\hline Quick shopping time & 4.15 \\
\hline More information about products & 4.09 \\
\hline Possibilities of delivery & 4.04 \\
\hline The ability to return goods & 4.00 \\
\hline Loyalty programs & 3.19 \\
\hline I like online shopping (It is a form of leisure time spending for me) & 2.90 \\
\hline
\end{tabular}


The calculation of the statistics of the Mann-Whitney $U$ test showed that the differences between the groups including younger people (under 24 years of age) and older respondents are statistically significant when it comes to identifying such motives for making purchases as: around-the-clock availability, more information about products, possibilities to find special products, loyalty programs and treating shopping as a form of spending free time. Individuals representing ages above 24 years of age more frequently than younger respondents indicate such motives for choosing online shopping as: around-the-clock availability, more information about products, possibilities to find special products. Younger people, in turn, more frequently indicate the matters including: loyalty programs and treating shopping as a form of spending free time. In all these cases, the asymptotic significance was lower than 0.05 .

Table 4. The results of the analysis with the use of the Mann-Whitney U test

\begin{tabular}{|l|c|c|c|c|}
\hline \multicolumn{1}{|c|}{$\begin{array}{c}\text { What motivates you to make } \\
\text { purchases online? }\end{array}$} & $\begin{array}{c}\text { Average for the } \\
\text { group of people } \\
\text { aged 18-24 } \\
\text { years }\end{array}$ & $\begin{array}{c}\text { Average for the } \\
\text { group of people } \\
\text { aged over 25 }\end{array}$ & $\begin{array}{c}\text { Value of the } \\
\text { Mann-Whitney } \\
\text { U test }\end{array}$ & $\begin{array}{c}\text { Asymptotic } \\
\text { bilateral } \\
\text { significance } \\
\mathrm{p}<0.05\end{array}$ \\
\hline Around-the-clock availability & 288.47 & 321.04 & $\mathrm{U}=34731.5$ & $\mathrm{p}=0.01$ \\
\hline Possibilities to find special products & 290.02 & 317.80 & $\mathrm{U}=35358.0$ & $\mathrm{p}=0.04$ \\
\hline More information about products & 288.78 & 320.40 & $\mathrm{U}=34856.5$ & $\mathrm{p}=0.02$ \\
\hline Loyalty programs & 312.79 & 270.12 & $\mathrm{U}=33413.0$ & $\mathrm{p}=0.003$ \\
\hline $\begin{array}{l}\text { I like online shopping (It is a form } \\
\text { of leisure time spending for me) }\end{array}$ & 313.23 & 269.21 & $\mathrm{U}=33236.0$ & $\mathrm{p}=0.003$ \\
\hline
\end{tabular}

Source: Authors' own study.

An important issue was also to determine what influences consumer decisions related to online shopping. Relating to those factors having a potential impact on the decisions to purchase online, the respondents had the 5-point Likert scale, the same as indicated above, at their disposal.

Studies have shown that the respondents opting for online shopping put most trust in their prior experience. They also rely - although rarely - on the advice of

Table 5. Average assessment of the factors affecting making purchases online by the respondents

\begin{tabular}{|l|c|}
\hline \multicolumn{1}{|c|}{ What motivates you to make purchases online? } & Average rating \\
\hline My experience & 4.33 \\
\hline Opinion of friends & 3.84 \\
\hline Opinion of family & 3.55 \\
\hline Current fashion trends & 3.06 \\
\hline Social media (like Facebook, etc.) & 3.02 \\
\hline Internet advert & 3.02 \\
\hline Products that support some events & 2.91 \\
\hline Loyalty programs & 2.86 \\
\hline Special personal offers (e-mail, newsletters, etc.) & 2.56 \\
\hline TV advert & 2.50 \\
\hline Famous persons using my searched products & 2.25 \\
\hline
\end{tabular}


friends and family. The following factors are significant as well: current fashion trends, social media and Internet adverts.

The calculation of the statistics of the Mann-Whitney U test showed that the differences between the groups, including younger people (under 24 years of age), and older respondents are statistically significant when it comes to such factors as making purchases online: opinion of friends, TV and Internet adverts, social media, selection of products that support some events, current fashion trends, famous persons using the searched products. These factors are more frequently indicated by persons belonging to the age bracket of 18-24 years. In all these cases, the asymptotic significance was lower than 0.05 .

Table 6. Results of the analysis of the Mann-Whitney U test

\begin{tabular}{|l|c|c|c|c|}
\hline $\begin{array}{c}\text { What motivates you to make } \\
\text { purchases online? }\end{array}$ & $\begin{array}{c}\text { Average for the } \\
\text { group of people } \\
\text { aged 18-24 years }\end{array}$ & $\begin{array}{c}\text { Average for the } \\
\text { group of people } \\
\text { aged over 25 }\end{array}$ & $\begin{array}{c}\text { Value of the } \\
\text { Mann-Whitney } \\
\text { U test }\end{array}$ & $\begin{array}{c}\text { Asymptotic } \\
\text { bilateral } \\
\text { significance } \\
\mathrm{p}<0.05\end{array}$ \\
\hline Opinion of friends & 308.63 & 278.84 & 35094.5 & $\mathrm{p}=0.04$ \\
\hline Current fashion trends & 314.18 & 267.22 & 32852.0 & $\mathrm{p}=0.001$ \\
\hline $\begin{array}{l}\text { Social media } \\
\text { (like Facebook, etc.) }\end{array}$ & 330.09 & 233.91 & 26424.5 & $\mathrm{p}=0.00$ \\
\hline Internet advert & 317.00 & 261.33 & 31715.0 & $\mathrm{p}=0.00$ \\
\hline $\begin{array}{l}\text { Products that support some } \\
\text { events }\end{array}$ & 309.71 & 276.59 & 34661.0 & $\mathrm{p}=0.02$ \\
\hline TV advert & 308.72 & 278.66 & 35061.0 & $\mathrm{p}=0.04$ \\
\hline $\begin{array}{l}\text { Famous persons using my } \\
\text { searched products }\end{array}$ & 317.40 & 260.48 & 31551.0 & $\mathrm{p}=0.00$ \\
\hline
\end{tabular}

Source: Authors' own study.

\section{Conclusions}

When considering the categories of products bought online, it should be noted that in the case of the most often bought product groups (such as clothing, shoes, or tickets to cultural events) the variable of age does not diversify the consumers' decisions. The results show, however, that certain groups of products constitute "typical" choices for the respondents in the age group of students, and other groups for people over 25 years of age.

The existence of statistically significant differences in the factors motivating younger and older people to shop online was also established. Students, more often than people over the age of 25 , make their decisions concerning conducting purchases online based on premises such as: loyalty programs and treating shopping as a form of spending free time. On the other hand, those over 25 years of age, more frequently than younger respondents, motivate their online purchasing decisions with factors of a more pragmatic nature as: around-the-clock availability, more information about products, possibility to find special products. 
The variable of age also diversifies the range of factors influencing the online purchases. Students, more frequently than the rest of the surveyed group, make their purchasing decisions under the influence of: opinion of friends, TV and Internet adverts, social media, as well as current fashion trends. During the selection of products, they are also guided by the fact whether they support some events, or whether a famous person uses the products searched by them.

The results of research have important managerial implications. Identified age-dependent differences in consumer behaviors may be included in the marketing strategies of online sales companies. Authors are aware of the limitations of the research that are involved in the lack of representativeness of the study sample. The study covered only the inhabitants of Podlaskie Voivodeship.

\section{Bibliography}

Bedyńska, S., Cypryańska, M. (eds.), Statystyczny drogowskaz. Praktyczne wprowadzenie do wnioskowania statystycznego, Wyd. Akademickie Sedno, Warszawa 2013, p. 185.

Feldy, M., E-konsumentów portret wlasny, "E-mentor", no. 4, 2012, pp. 77-81.

Gemius, E-commerce w Polsce 2016. Gemius dla e-Commerce Polska, 2016, https://www.gemius.pl/ wszystkie-artykuly-aktualnosci/nowy-raport-o-polskim-e-commerce-juz-dostepny.html (access: 20.02.2017).

GUS, Społeczeństwo informacyjne w Polsce w 2016r., 2016a, http://stat.gov.pl/obszary-tematyczne/nauka-i-technika-spoleczenstwo-informacyjne/spoleczenstwo-informacyjne/spoleczenstwo-informacyjne-w-polsce-w-2016-roku,2,6.html (access: 15.02.2017).

GUS, Spoteczeństwo informacyjne w Polsce. Wyniki badań statystycznych z lat 2012-2016, 2016b, http:// stat.gov.pl/obszary-tematyczne/nauka-i-technika-spoleczenstwo-informacyjne/spoleczenstwo-informacyjne/ (access: 15.02.2017).

Jaciow, M., Wolny, R., Polski e-konsument. Typologia zachowania, Onepress, Gliwice 2011.

Maciejewski, G., Zakupy on-line w opiniach e-konsumentów z wybranych krajów Europy, "Studia i Prace WNEiZ US", vol. 43, no. 3, 2016, pp. 219-230.

Pacut, M., Zachowania nabywcze polskich e-konsumentów na rynku, "Studia i Prace WNEiZ US", vol. 43, no. 3, 2016, pp. 319-328.

Passyn, K.A., Diriker, M., Settle, R.B., Images of Online Versus Store Shopping: Have the Attitudes of Men and Women, Young and Old Really Changed?, "Journal of Business \& Economics Research", vol. 9, no. 1, 2011, pp. 99-110.

Rajamma, R.K., Paswan, A.K., Ganesh, G., Services Purchased at Brick and mortar Versus Online Stores, and Shopping Motivation, "Journal of Services Marketing”, vol. 21, no. 3, 2007, pp. 200-212.

Schultz, D.E., Block, M.P., U.S. Online Shopping: Facts, Fiction, Hopes and Dreams, "Journal of Retailing and Consumer Services", vol. 23, 2015, pp. 99-106.

TNS, Raport e-zakupy 2016,http://www.tnsglobal.pl/wp-content/uploads/2016/11/raport_e_ZAKUPY_2016. pdf (access: 20.02.2017).

Toufaily, E., Souiden, N., Ladhari, R., Consumer Trust Toward Retail Websites: Comparison between Pure Click and Click-and-Brick Retailers, "Journal of Retailing and Consumer Services", vol. 20, no. 6, 2013, pp. 538-548.

Wolny, R., Zmiany zachowań nabywczych polskich e-konsumentów, "Studia Ekonomiczne”, Zeszyty Naukowe Uniwersytetu Ekonomicznego w Katowicach, no. 270, 2016, pp. 285-293. 
Pobrane z czasopisma Annales H - Oeconomia http://oeconomia.annales.umcs.pl Data: 26/04/2023 10:17:13

\section{Customer Preferences Related to Shopping Online}

Nowadays online shopping is becoming more popular among Polish consumers. The aim of the article is to establish the existence of statistically significant differences between certain aspects of the behaviour of consumers when shopping online and their age. The empirical base for the article comprises the material obtained as a result of a survey carried out on a sample of 597 people buying over the Internet.

\section{Preferencje klientów związane z zakupami online}

Zakupy online stają się coraz bardziej popularne wśród polskich konsumentów. Niniejszy artykuł ma na celu wykazanie istnienia statystycznie istotnych różnic między wybranymi aspektami zachowań konsumentów podczas zakupów online a ich wiekiem. Bazę empiryczną opracowania stanowią wyniki badań diagnostycznych przeprowadzonych techniką CAWI na próbie 597 osób dokonujących zakupów przez Internet. 